\title{
Dynamics of Watta Satta Marriages in Rural Areas of Southern Punjab Pakistan
}

\author{
Roomana Naz Bhutta1, Imtiaz Ahmad Warich1, ArslanIjaz Bhutta2, Nouman Ijaz Bhutta3, \\ Muhammad Ali ${ }^{*}$ \\ ${ }^{1}$ Department of Sociology, Ghazi University, Dera Ghazi Kham, Pakistan \\ ${ }^{2}$ Department of Sociology, Government Degree College for Boys Rajanpur, Rajanpur, Pakistan \\ ${ }^{3}$ MBA Iqra University, Islamabad, Pakistan \\ ${ }^{4}$ Department of Statistics, Ghazi University, Dera Ghazi Kham, Pakistan \\ Email:"alibapa76@gmail.com
}

Received 20 August 2015; accepted 26 December 2015; published 29 December 2015

Copyright (C) 2015 by authors and Scientific Research Publishing Inc.

This work is licensed under the Creative Commons Attribution International License (CC BY).

http://creativecommons.org/licenses/by/4.0/

(c) (i) Open Access

\begin{abstract}
Watta satta marriage is due to several reasons as like social, cultural and economic. Watta satta marriages subsist in rural areas of Southern Punjab Pakistan. Such marriages are usually compromised marriages and this issue demands investigation to explore the main reasons of this custom and related problems created by it. The researchers recognized the causes of watta satta and certain strategies to control it. The sample of present study consists of all married males and females from Southern Punjab Pakistan. Researchers also investigated that illiteracy and poverty are the major causes. The Chi-Square test was applied to see the correlation and the result showed significant and direct relationship between variables.
\end{abstract}

\section{Keywords}

Watta Satta, Marriage, Rural Areas, Southern Punjab, Pakistan

\section{Introduction}

The exchange marriage (watta satta), a traditional way of marriage particularly in rural areas of Pakistan, is the exchange of brides between two families. In this practice of bartering bride, at the time of marriage, both families trade brides. Bride exchange, known as birder in Turkey, badal in Jordon and Palestine and Watta satta or baddo in Pakistan (literally, "give-take"), usually involves the simultaneous marriage of a brother-sister pair from two households. Surprisingly, watta satta accounts for about a third of all marriages in rural areas of Pakis-

${ }^{*}$ Corresponding author.

How to cite this paper: Bhutta, R.N., Warich, I.A., Bhutta, A., Bhutta, N.I. and Ali, M. (2015) Dynamics of Watta Satta Marriages in Rural Areas of Southern Punjab Pakistan. Open Journal of Social Sciences, 3, 166-178.

http://dx.doi.org/10.4236/jss.2015.312018 
tan. Watta satta is a tradition in many families in Punjab and Sindh.

Exchange marriage has also been documented in southern India, parts of China [1] and, at least in the 20th century, which seems to have been common among the Hindus of Punjab as well [2]. Early anthropological accounts matrimonial exchange in some West African societies also point out the reason "retaliatory" stands out in this document [3]. Interest in these cases, is often a reaction to the wife "malfeasance" (like letting her husband) that her brother's marriage suspended.

In watta satta, a brother and sister are married with another couple from another family, often close relative. More rarely, uncle-niece pair, or two cousins are perhaps exchanged for a home, but this is relatively uncommon, and is only done when sibling in appropriate age groups are not available.

In particular, if there is a large age difference between two couples caught up in watta Satta appreciably, the second pair may still not be married and possibly not even born! There are also cases, though very few, where the second pair is no longer married or living. Exchange marriage inbreeding clearly facilitates forging a double bond in the same two families, but this seems to be the motivation soul for the provision in rural Pakistan [4].

Exchange marriages are more common among couples who are blood relatives. For example, first cousin marries a brother-sister watta. The sister in law and their husbands are essentially cousins too.

Exchange marriage provides security for both families, but at the other end is a double-edged sword. A husband who abuses or mistreats his wife in this provision can accept his brother to strike back in kind against his sister. Such reciprocal intimidation operating across marriages can be trustworthy and therefore can thwart unproductive marital upshots. There is no difference in the rate of divorce or separation in watta satta marriages and conventional marriages. However, families who involve themselves in exchanges marriages lead a stressful life as contrast with those of conventional single-marriages [4].

The practice of watta satta involves the mutual exchange of possessions, eliminating the need to provide the dowry as both parties are in a position of equality and is perhaps indented to ensure control over the treatment of a daughter as the daughter of the family is a kind of hostage. However, when the relationship in one such couple faces obscurities, the other partner is often harmfully affected as well. According to the ideal pattern, married women for trade are more firmly fixed to her husband. Marriage by exchange accepted to be durable and, though not often break, is still regarded as an exception when the divorce.

A married woman who returns home as a result of marital discord is seen as deep disgrace and it is believed that the watta satta agreement can help prevent this in the case of exchange of marriage, the wife can escape in the compound of his custodian. However if women tell her guardian that the only reason for her departure is that the husband criticizes her, she likely has little support from him and the rest of her family. Family may ask her to return without delay or try to convince her to return to her husband because when he comes to claim a lot of pressure will be exerted on it if they refuse. No fine shall be imposed to the husband if the husband is found to be the culprit. The only way her guardian can adopt is to allow her divorcing which breaks down paired marriage [5].

Exchange marriages often lead to complicated situations as abuse, slaps, kicks, punches and blows that are physical abuse. There are also psychological abuse, constant belittling, intimidation, humiliation and sex courses. A women's reaction to abuse is often limited due to lower economic capacity and support, concern for the children's emotional dependence, lake of education, the support of friends and family. In Pakistan, divorce is a social stigma of women. Abused women have never told anyone about the abuse.

Psychological consequences of abuse are more severe than its physical effects. The experience of abuse corrodes women self-esteem and puts them at a greater risk for a number of metal disorders like depression, post traumatic stress disorder, suicide, alcohol, and drug abuse. Children witness marital violence face increased risk for emotional and behavior problems, including anxiety, depression, poor school performance, low self esteem, nightmares and disobedience. Boys turn to drug and girls become severely depressed and sometimes totally refuse to get married. Children under 12 years have learning emotional and behavior problems almost 6 - 7 times more compared to children of no abusive parents [6].

Exchange marriage is also accountable for conflicts and stress. Conflict between one of the couple keeps the whole family and their counterpart family under acute stress and has dangerous effect on psychology of parents and children.

\subsection{Significance of Study}

Watta satta (exchange marriage) is prevailing everywhere in Pakistan especially in Southern Punjab. Its occur- 
rence is due to several reasons such as social, cultural and economic. Family is a very prominent and basic institution. In rural areas of Pakistan, family is back bone of society and marriage is also considered as a fundamental responsibility of family. Decisions of marriages are being done by the head of family. Traditional societies mostly preferred Indo gammy. This custom of exchange marriage is a stone-age custom. However it is not liked by many of peoples yet it is practiced due to various economic and customary reasons. Practice of watta satta is most common in indo gammy but also practice in exogamy. In watta satta Choice of marriage is not given to the male or female, who are going to make a family. It results divorce, separations and tensions among families. Husband and wife mostly fail to create mutual understanding. No doubt watta satta reduces divorce rate but on the other hand it generated different psychological and social problems even socialization of children also affected. This study will help us to understand the various factors that are responsible for the practice of watta satta (exchange marriages).

\subsection{Objectives of the Study}

Following were the objectives:

1) To explore the socio-economic factors responsible watta satta marriages.

2) To identify the consequences of watta satta marriages.

\subsection{Literature Reviews}

[7] Carsten stated that similarity and compatibility between the couple was not simply due to sharing substance: the being "of one blood” attributed to all members of the kin group. Ties of kinship were also created, as strong demonstrated for the "process of kinship" in Malaysia, marriage, feeling and exchange created and maintained bonds of relatedness. He pointed out that although one intention of a kin marriage might be to strengthen family ties, if conflict did occur between husband and wife, and particularly if they divorced, wider relationships might become embroiled in the dispute.

[8] Ahmed described that another variation of forced marriage was exchange marriages known as "Shighaar" or "watta satta”. In such a situation a brother and sister were married off to another pair of siblings. He noted that discord in one family tended to affect the other family.

[9] Chaudhry studied the attitude of rural women towards exchange marriages in district Jhang. The study was conducted on 120 exchanged Women. The researchers found that more than half of the respondents preferred exchange marriage for the sake of traditional values. A vast majority of the respondents were not preferred the exchange marriage for the sake of affection. The study further found that a huge majority of respondents were in favor of their daughters or sons to get exchange marriage. It was also found that majority of respondents reported that their in-laws had revengeful behavior with them.

[10] Jacoby and Mansuri reported that a complex array of cultural practices around marriage appeared to substitute or compensate, at least in part, for poor enforcement of marital law. For example watta satta was surprisingly common in rural Pakistan, with more than one in three women in a watta satta marriage. While that practice was widely perceived as detrimental to women, analysis using Pakistan Rural House Hold Survey (PRHS) 2004 suggested that an exchange of daughters actually constrained abuse on the part of either family to a considerable degree. Not only women in watta satta marriages were less likely to endure domestic violence; they also suffered significantly less depression and marital estrangement than women in non watta satta marriages. It was therefore important to distinguish such potentially protective practices from egregious crimes such as Karo Kari and honors killing which might be community sanctioned, often through appeal to customary legal institution. It also elucidated why customary practices that afforded informal protection, however imperfect, were likely to persist unless adequate legal refunds were put in place and were enforceable.

[11] Coomaraswamy found that another customary practice of marriage in south Asia that was violence towards women was the practice of child marriage. In Nepal $40 \%$ of marriages involved girls under the age of fifteen. In Pakistan the watta satta marriage was another form of marriage that violated the rights of women. Women became part of barter between men. A woman was given in marriage to a marriage to a man in return for another woman. These traditional forms of marriage held together by the concept of honors and community deeply oppressed women but were so firmly embedded in South Asia that unless there was concerted action with the State taking the lead, such practices would never change.

[5] Saeed observed that watta satta or exchange marriage custom was widely followed in tribal villages of 
Sulaiman mountain range. There were different reasons of following that custom in tribal villages. Girls were considered burden on family because of their marriage problems. Without watta satta custom, girls would never get married whereas outside families demanded dowry and it saved them from dowry curse. In such situation both families gave dowry according to their capacity and did not write anything in Nikahnama except Mehar. Otherwise, dowry was demanded or given on equal basis. It was done so that girl s' in laws could not quarrel and she lived with dignity and prestige. One major reason of following the custom was property so that a stranger might not get share of his wife's inherited property.

[12] World Bank (2005) reported that Exchanged marriage might also serve as a mechanism for cancelling out dowry assets (from a son) and liabilities (from a daughter) in the parental "balance sheet". The advantage of marrying ones daughter into ones son "s wife" s family was that there was no need, in principle, to exchange dowry assets at all. World bank also reported that one qualification was that some of the "rents" accruing to women whose families were able to arrange a watta satta marriage might be appropriated by their brothers via a reallocation of parental transfers in favor of sons. Even if utilities were perfectly transferable, however, women in watta eligible families would still share in the overall wealth effect.

[13] Chaudhry observed that in many early marriages or engagements were performed under watta satta custom. Early age marriage was reported widespread due to socio economic reason and in the name of religion. Girls were married when they reached the age of puberty. A man could marry out of the family or relatives but with the consent of parents. Marriage of own choice was not accepted by many families. Watta satta was followed because girls were considered a burden on the family. It was practiced in all families. Watta satta was the major reason behind divorce. Many women participants believed that a few women knew their rights but they did not raise voice due to scare of men. He reported that among the conventional customs and practices reciprocal marriage (watta satta) was a common practice (64 percent) in Tehsils but it was very common in Tehsil Taunsa and Jatoi. However, it was least practiced in Multan and Muzaffargarh

[4] Jacoby and Mansuri mentioned in the paper, Bride Exchange and Women's Welfare in Rural Pakistan, conducted by the World Bank stated that a bride exchange accompanied by mutual retaliatory threats could be mechanism to coordinate the actions of two sets of in-laws, each of whom wished to restrain their son-in-laws, but only had the ability to restrain their sons. They found that there was no difference in the rate of divorce or separation (around 1.5 percent) between women in watta satta marriages and in conventional marriages. They stressed that exchange marriage might serve as mechanism to curtail the financial burden of dowry. A vast majority of watta satta marriages (94 percent) involved at least one brother-sister pair, and most (72 percent) involved a brother-sister pair on both sides. The second most popular watta satta arrangement (16 percent) was when at least one of the households (but rarely both) contributed an uncle-niece pair. The study added that various other combinations occurred as well, though none in significance numbers. Even more striking was the extent of marriage with in the clan and caste, 77 percent women were married a blood relative mostly, mostly first cousins with a preference for the paternal side, 4.13 percent was married someone not related by blood but within the same caste.

[14] World Bank policy research paper found that watta satta marriages, a years old practice of bartering bride for bride, helped to reduce the probability of domestic abuse and was clearly in the interest of women regard less of whether the institution was motivated by parent s' altruism towards their daughters or by their desire to maintain family honor.

[15] Charsley stated that watta satta epitomized the dangers of the double rishta (relationship). It carried dangers, running the risk of direct revenge being taken on your daughter should your son'smarriage run into difficulty. Watta satta represented the point where the balance shifted in the risk s and benefits of close kin marriage; where an attempt to reduce dangers by marrying close kin ended up producing other equally serious risks. Rifts within the family were a hazard of all unsuccessful consanguineous marriages, but in watta satta each side had the potential to inflict a direct blow to the other s' family honor and caused suffering to a daughter of the other s' house.

[16] Cheema pointed out that watta satta and cousin marriages were designed to prevent break up of property. Aside from deprivation of right to acquire and own property, women themselves were treated as property.

[17] Najam (2010) found that in Pakistan, feudal and tribal customs say that property be kept in the family. It is not special for girls to be married to a fatherly uncle or aunt's sons so that control over the land (Jagir) is weakened which would happen if a daughter married an outsider. Feudal do not want their Jagirs dismembered on every relation. He also says that there are many causes involving in watta satta marriage system like Tribali- 
zation of formal laws, Brutalization of society, awareness-one of the reasons, economic decline.

[18] Dawn reported that the poor, rural parents are forced their daughters for welfare and safeguards they want. As for women who may be forced into exchange marriages by their parents for selfish reasons to protect land holdings for their male. The tradition is planned both to exercise some control over the money a girl takes out of her own family on marriage, and the amount that comes in with her brother's bride.

\section{Methodology}

The universe for the present study comprised of the all married people who practiced watta satta in rural area of Southern Punjab Pakistan. For the present study purposive sampling technique was used for the selection of respondents. The sample consisted of 300 respondents. The researchers collected the data from respondents through interview schedule. The data were tabulated statistically analyzed to bring it into a computer have various values and their analysis. In order to bring the data into comparable form, percentages of various categories of data were used in the present study. Chi-Square test was applied to examine relationship between independent and dependent variables. Education level and Poverty both were taken as independent variables, whereas on the other hand watta satta practice was considered as dependent variable. Watta satta practice was a strong rural custom which could be changed by changing level of education. Rural areas of Southern Punjab of Pakistan were suffered from poverty with low education level, that's why the watta satta custom was highly prevailed there.it was the main factor to choose these variable (education level and poverty).

\section{Hypothesis}

These were the following hypothesis formulated for our research:

1) Poor People are more inclined to watta satta marriages.

2) Lake of education is connected with watta satta marriages.

\section{Conceptualization and Operationalization}

\subsection{Watta Satta}

The exchange marriage (watta satta), a traditional way of marriage particularly in rural areas of Pakistan, is the exchange of brides between two families. In this practice of bartering bride, at the time of marriage, both families trade brides.

\subsection{Illiteracy}

The state of being illiterate, or uneducated; specifically, inability to read and write. For the present study, this term was operationalized as the lack of basic education in rural areas.

\subsection{Poverty}

The condition of having little or no money, goods, or means of support, condition of being poor. For the present study, this term was operationalized as the low income level of the people of rural areas.

\section{Results and Discussions}

Table 1 shows that majority 57 percent of the respondents were male and 43 percent of respondents were female. This ratio shows that the majority of respondents were males. It is because that the female in rural areas were not willing to give response.

Table 2 shows that 43.33 percent of the respondents were in the age category of 41 - 50, 25.67 percent of the respondents were 51 - 60, 15.33 percent of the respondents were 31 - 40, 9.67 percent of the respondents were 20 - 30 and 6 percent of respondents were Above 61. This ratio shows that near about seventy percent of the respondents were in the age category of $41-60$.

Table 3 shows that 54.33 percent of the respondents were illiterate, 24.0 percent of the respondents were literate-primary, 11.33 percent of the respondents were middle-matric, 6.67 percent of the respondents were inter-graduation qualification and 3.67 percent of the respondents were masters or above. This ratio shows that 
Table 1. Percentage distribution of the respondents according to their gender.

\begin{tabular}{ccc}
\hline Gender of the respondents & Frequency & Percent \\
\hline Male & 171 & $57 \%$ \\
Female & 129 & $43 \%$ \\
Total & 300 & $100.0 \%$
\end{tabular}

Table 2. Percentage distribution of the respondents according to their age.

\begin{tabular}{cccc}
\hline Age of the respondents & Frequency & Percent \\
\hline $20-30$ & 29 & $9.67 \%$ \\
$31-40$ & 46 & $15.33 \%$ \\
$41-50$ & 130 & $43.33 \%$ \\
$51-60$ & 77 & $25.67 \%$ \\
Above 61 & 18 & $6 \%$ \\
Total & 300 & $100.0 \%$ \\
\hline
\end{tabular}

ratio of illiterate respondents was high because no educational facilities provided in rural areas of southern Punjab.

Table 4 shows that 88.0 percent of the respondents were having joint family system and 12.0 percent of the respondents were having nuclear family system. This ratio shows that the majority of respondents belonged from joint family system. It is because that the people of rural areas feel prestige to live together.

Table 5 shows that majority 69.0 percent of the respondent's monthly income was 1000 - 10,000, 21.0 percent of the respondent's monthly income was 10,000 - 20,000, and 10 percent of the respondent's monthly income was above 20000. This ratio shows that the majority of respondent's monthly family income was 1000 10,000 . People of rural areas do not have enough resources for earning.

Table 6 shows that majority 72.0 percent of the respondents preferred paternal cousin marriage for their daughters, 20.0 percent of the respondents favored maternal cousin marriage for their daughters and 8.0 percent of the respondents chosen out of family marriage for their daughters. This ratio shows that the majority of respondents preferred paternal cousin marriage for their daughters for the reason that in rural area father's relatives considered more prestigious than mother's.

Table 7 shows that majority 84.67 percent of the respondents favored paternal cousin marriage for their son, 8.0 percent of the respondents chosen maternal cousin marriage their son and 7.33 percent of the respondents also did marriages of their sons out of family. This ratio shows that the majority of respondents preferred paternal cousin marriage for their sons because people of rural considered the father's relatives more influential than mother's.

Table 8 shows that majority 84.0 percent of the respondents strongly agreed that watta satta is a rural custom, 8.0 percent of the respondents agreed that watta satta is a rural custom, 4.0 percent of the respondents remained undecided and neutral, 2.67 percent of the respondents were disagree that watta satta is a rural custom and 1.33 percent of the respondents were strongly disagreed with this statement.

Table 9 shows that majority 80.0 percent of the respondents strongly agreed that watta satta is religiously perceived, 7.33 percent of the respondents agreed that watta satta is religiously perceived, 6.33 percent of the respondents disagreed that watta satta is religiously perceived, 3.67 percent of the respondents strongly disagreed with the statement and 2.67 percent of the respondents remained undecided and neutral. This ratio shows that the majority of respondents believed that watta satta is religiously perceived.

Table 10 shows that majority 79.0 percent of the respondents strongly agreed that watta satta is security for women, 9.33 percent of the respondents disagreed that watta satta is security for women, 6.33 percent of the respondents remained undecided and neutral, 3.67 percent of the respondents strongly disagreed that watta satta is security for women and 1.67 percent of the respondents agreed that watta satta is security for women. This ratio shows that the majority of respondents strongly agreed that watta satta is security for women in rural areas. 
Table 3. Percentage distribution of the respondents according to their education level.

\begin{tabular}{ccc}
\hline Education level of the respondents & Frequency & Percent \\
\hline Illiterate & 163 & $54.33 \%$ \\
Literate-primary & 72 & $24.0 \%$ \\
Middle-matric & 34 & $11.33 \%$ \\
Inter-graduation & 20 & $6.67 \%$ \\
Master-above & 11 & $3.67 \%$ \\
Total & 300 & $100.0 \%$ \\
\hline
\end{tabular}

Table 4. Percentage distribution of the respondents according to their family system.

\begin{tabular}{ccc} 
Family system do you belong & Frequency & Percent \\
\hline Nuclear & 36 & $12.0 \%$ \\
Joint & 264 & $88.0 \%$ \\
Total & 300 & $100.0 \%$ \\
\hline
\end{tabular}

Table 5. Percentage distribution of the respondents according to their monthly income.

\begin{tabular}{cccc}
\hline Monthly income & Frequency & Percent \\
\hline $1000-10,000$ & 207 & $69.0 \%$ \\
$10,000-20,000$ & 63 & $21.0 \%$ \\
Above 20,000 & 30 & $10 \%$ \\
Total & 300 & $100.0 \%$
\end{tabular}

Table 6. Percentage distribution of the respondents according to their preference to marry their daughters.

\begin{tabular}{ccc}
\hline Like to marry their daughters & Frequency & Percent \\
\hline Maternal cousin & 60 & $20.0 \%$ \\
Paternal cousin & 216 & $72.0 \%$ \\
Out of family & 24 & $8.0 \%$ \\
Total & 300 & $100.0 \%$ \\
\hline
\end{tabular}

Table 7. Percentage distribution of the respondents according to their preference to marry their sons.

\begin{tabular}{ccc}
\hline Like to marry their sons & Frequency & Percent \\
\hline Maternal cousin & 24 & $8.0 \%$ \\
Paternal cousin & 254 & $84.67 \%$ \\
Out of family & 22 & $7.33 \%$ \\
Total & 300 & $100.0 \%$ \\
\hline
\end{tabular}

Table 11 shows that majority 75.34 percent of the respondents strongly agreed that watta satta guarantee's the equal treatment, 11.0 percent of the respondents disagreed that watta satta guarantee's the equal treatment, 10.33 percent of the respondents remained undecided and 3.33 percent of the respondents agreed that watta satta guarantee's the equal treatment. This ratio shows that the majority of respondents strongly agreed that watta satta guarantee's the equal treatment of both parties in rural areas of southern Punjab. 
Table 8. Percentage distribution of the respondents according to their view about watta satta is a rural custom.

\begin{tabular}{ccc}
\hline Watta satta is rural custom & Frequency & Percent \\
\hline Agree & 24 & $8.0 \%$ \\
Strongly agree & 252 & $84.0 \%$ \\
Neutral & 12 & $4.0 \%$ \\
Disagree & 8 & $2.67 \%$ \\
Strongly disagree & 4 & $1.33 \%$ \\
Total & 300 & $100.0 \%$ \\
\hline
\end{tabular}

Table 9. Percentage distribution of the respondents according to their view about watta satta is religiously perceived.

\begin{tabular}{|c|c|c|}
\hline Watta satta is religiously perceived & Frequency & Percent \\
\hline Agree & 22 & $7.33 \%$ \\
\hline Strongly agree & 240 & $80.0 \%$ \\
\hline Neutral & 8 & $2.67 \%$ \\
\hline Disagree & 19 & $6.33 \%$ \\
\hline Strongly disagree & 11 & $3.67 \%$ \\
\hline Total & 300 & $100.0 \%$ \\
\hline
\end{tabular}

Table 10. Percentage distribution of the respondents according to their view about watta satta is security for women.

\begin{tabular}{ccc}
\hline Watta satta is security for women & Frequency & Percent \\
\hline Agree & 5 & $1.67 \%$ \\
Strongly agree & 237 & $79.0 \%$ \\
Neutral & 19 & $6.33 \%$ \\
Disagree & 28 & $9.33 \%$ \\
Strongly disagree & 11 & $3.67 \%$ \\
Total & 300 & $100.0 \%$ \\
\hline
\end{tabular}

Table 11. Percentage distribution of the respondents according to their view about watta satta guarantee's the equal treatment.

\begin{tabular}{|c|c|c|}
\hline Watta satta guarantee's the equal treatment & Frequency & Percent \\
\hline Agree & 10 & $3.33 \%$ \\
\hline Strongly agree & 226 & $75.34 \%$ \\
\hline Neutral & 31 & $10.33 \%$ \\
\hline Disagree & 33 & $11.0 \%$ \\
\hline Total & 300 & $100.0 \%$ \\
\hline
\end{tabular}

Table 12 shows that majority 85.33 percent of the respondents strongly agreed that watta satta is a way to protect the land division, 5.34 percent of the respondents disagreed that watta satta is a way to protect the land division, 4.0 percent of the respondents remained undecided and neutral, 3.33 percent of the respondents agreed that watta satta is a way to protect the land division and 2.0 percent of the respondents strongly disagreed with the statement. This ratio shows that the majority of respondents strongly agreed that watta satta is a way to protect the land division.

Table 13 shows that majority 87.33 percent of the respondents strongly agreed that watta satta gives prestige 
to family, 4.0 percent of the respondents remained undecided and neutral, 3.67 percent of the respondents disagreed that watta satta gives prestige to family, 3.67 percent of the respondents agreed that watta satta gives prestige to family and 1.34 percent of the respondents strongly disagreed with the statement. This ratio shows that the majority of respondents alleged that watta satta gives prestige to family.

Table 14 shows that majority 80.67 percent of the respondents strongly agreed that dowry supports watta satta, 7.67 percent of the respondents disagreed that dowry supports watta satta, 5.33 percent of the respondents agreed that dowry supports watta satta, 4.33 percent of the respondents remained undecided and neutral and 2.0 percent of the respondents strongly disagreed with the statement. This ratio shows that the majority of respondents strongly believed that dowry supports watta satta.

Table 15 shows that majority 82.67 percent of the respondents strongly agreed that economic burdenis a cause of watta satta, 7.33 percent of the respondents remained undecided and neutral, 5.0 percent of the respondents agreed that economic burdenis a cause of watta satta, 4.33 percent of the respondents disagreed that economic burdenis a cause of watta satta and 0.67 percent of the respondents strongly disagreed with the statement. This ratio shows that the majority of respondents viewed that economic burdenis a cause of watta satta in rural areas.

Table 16 shows that majority 86.34 percent of the respondents strongly agreed that disturbance in one family leads to disturbance in another family, 4.33 percent of the respondents remained undecided and neutral, 3.33

Table 12. Percentage distribution of the respondents according to their view about watta satta is a way to protect the land division.

\begin{tabular}{|c|c|c|}
\hline Watta satta is a way to protect the land division & Frequency & Percent \\
\hline Agree & 10 & $3.33 \%$ \\
\hline Strongly agree & 256 & $85.33 \%$ \\
\hline Neutral & 12 & $4.0 \%$ \\
\hline Disagree & 16 & $5.34 \%$ \\
\hline Strongly disagree & 6 & $2.0 \%$ \\
\hline Total & 300 & $100.0 \%$ \\
\hline
\end{tabular}

Table 13. Percentage distribution of the respondents according to their view about watta satta gives prestige to family.

\begin{tabular}{ccc}
\hline Watta satta gives prestige to family & Frequency & Percent \\
\hline Agree & 11 & $3.67 \%$ \\
Strongly agree & 262 & $87.33 \%$ \\
Neutral & 12 & $4.0 \%$ \\
Disagree & 11 & $3.67 \%$ \\
Strongly disagree & 4 & $1.34 \%$ \\
Total & 300 & $100.0 \%$ \\
\hline
\end{tabular}

Table 14. Percentage distribution of the respondents according to their view about watta satta discourage dowry.

\begin{tabular}{ccc}
\hline Watta satta discourage dowry & Frequency & Percent \\
\hline Agree & 16 & $5.33 \%$ \\
Strongly agree & 242 & $80.67 \%$ \\
Neutral & 13 & $4.33 \%$ \\
Disagree & 23 & $7.67 \%$ \\
Strongly disagree & 6 & $2.0 \%$ \\
Total & 300 & $100.0 \%$ \\
\hline
\end{tabular}


percent of the respondents agreed that disturbance in one family leads to disturbance in another family, 3.33 percent of the respondents strongly disagreed with the statement and 2.67 percent of the respondents disagreed that disturbance in one family leads to disturbance in another family. This ratio shows that the majority of respondents said that trouble in one family leads to disorder in another family.

Table 17 shows that majority 79.0 percent of the respondents strongly agreed that watta satta marriages are more durable than normal marriages, 8.67 percent of the respondents disagreed that watta satta marriages are more durable than normal marriages, 3.0 percent of the respondents remained undecided and neutral, 4.0 percent of the respondents agreed that watta satta marriages are more durable than normal marriages and 3.33 percent of the respondents strongly disagreed with the statement. This ratio shows that the majority of respondents strongly agreed that watta satta marriages are more strongand long lasting than normal marriages.

Table 18 shows that majority 88.67 percent of the respondents strongly agreed that illiteracy is also one of the causes of watta satta, 4.0 percent of the respondents agreed that illiteracy is also one of the causes of watta satta, 3.33 percent of the respondents remained undecided and neutral, 3.33 percent of the respondents disagreed that illiteracy is also one of the causes of watta satta and 0.67 percent of the respondents strongly disagreed with the

Table 15. Percentage distribution of the respondents according to their view about economic burden is a cause of watta satta.

\begin{tabular}{ccc}
\hline Economic burden is a cause of watta satta & Frequency & Percent \\
\hline Agree & 15 & $5.0 \%$ \\
Strongly agree & 248 & $82.67 \%$ \\
Neutral & 22 & $7.33 \%$ \\
Disagree & 13 & $4.33 \%$ \\
Strongly disagree & 2 & $0.67 \%$ \\
Total & 300 & $100.0 \%$ \\
\hline
\end{tabular}

Table 16. Percentage distribution of the respondents according to their view about disturbance in one family leads to disturbance in another family.

\begin{tabular}{ccc}
\hline Disturbance in one family leads to disturbance in another family & Frequency & Percent \\
\hline Agree & 10 & $3.33 \%$ \\
Strongly agree & 259 & $86.34 \%$ \\
Neutral & 13 & $4.33 \%$ \\
Disagree & 8 & $2.67 \%$ \\
Strongly disagree & 10 & $3.33 \%$ \\
Total & 300 & $100.0 \%$ \\
\hline
\end{tabular}

Table 17. Percentage distributions of the respondents according to their view about watta satta marriages are more durable than normal marriages.

\begin{tabular}{ccc}
\hline Watta satta marriages are more durable than normal marriages & Frequency & Percent \\
\hline Agree & 12 & $4.0 \%$ \\
Strongly agree & 237 & $79.0 \%$ \\
Neutral & 15 & $3.0 \%$ \\
Disagree & 26 & $8.67 \%$ \\
Strongly disagree & 10 & $3.33 \%$ \\
Total & 300 & $100.0 \%$ \\
\hline
\end{tabular}


statement. This ratio shows that the majority of respondents thought illiteracy is also one of the causes of watta satta.

Table 19 shows that majority 71.0 percent of the respondents strongly agreed that teen age girl be married to an old man in watta satta, 19.33 percent of the respondents remained undecided and neutral, 3.67 percent of the respondents strongly disagreed that teen age girl be married to an old man in watta satta, 3.33 percent of the respondents agreed that teen age girl be married to an old man in watta satta and 2.67 percent of the respondents disagreed that teen age girl be married to an old man in watta satta. This ratio shows that the majority of respondents believed that it is common practice in rural areas that teen age girl be married to an old man in watta satta.

Table 20 shows that majority 80 percent of the respondents strongly agreed that children should be married in watta satta marriage arrangements, 7.0 percent of the respondents remained undecided and neutral, 6.33 percent of the respondents agreed that children should be married in watta satta marriage arrangements, 3.66 percent of the respondents disagreed that children should be married in watta satta marriage arrangements and 3.0 percent of the respondents strongly disagreed with the statement. This ratio shows that the majority of respondent strongly agreed that exogamy support that children should be married in watta satta marriage arrangement.

Table 21 shows there is relationship between illiteracy and the rate of watta satta. The gamma value is positive which shows the relationship between variables is direct means higher the illiteracy higher will be watta satta. This shows that alternative hypothesis is accepted and null hypothesis is rejected.

Table 22 shows there is relationship between economic conditions and the rate of watta satta. The gamma value is positive which shows the relationship between variables is direct means greater the poverty, greater will be watta satta. This shows that alternative hypothesis is accepted and null hypothesis is rejected.

\section{Summary and Conclusion}

In watta satta, one brother and sister are married to another pair from another family—often close relative. More rarely, uncle-niece pair, or two cousins, may be exchanged by one household but this is relatively unusual, and practiced only. Exchange marriages are more prevalent among couples who are blood relatives when first-cousin, for example, marries in a brother-sister watta, the resulting sister in laws and their husbands are necessarily

Table 18. Percentage distribution of the respondents according to their view about illiteracy is also one of the causes of watta satta.

\begin{tabular}{ccc}
\hline Illiteracy is also one of the causes of watta satta & Frequency & Percent \\
\hline Agree & 12 & $4.0 \%$ \\
Strongly agree & 266 & $88.67 \%$ \\
Neutral & 10 & $3.33 \%$ \\
Disagree & 10 & $3.33 \%$ \\
Strongly disagree & 2 & $0.67 \%$ \\
Total & 300 & $100.0 \%$ \\
\hline
\end{tabular}

Table 19. Percentage distribution of the respondents according to their view that a teenage girl is married to an old man in watta satta.

\begin{tabular}{ccc}
\hline Teenage girl is married to an old man in Watta satta & Frequency & Percent \\
\hline Agree & 10 & $3.33 \%$ \\
Strongly agree & 213 & $71.0 \%$ \\
Neutral & 58 & $19.33 \%$ \\
Disagree & 8 & $2.67 \%$ \\
Strongly disagree & 11 & $3.67 \%$ \\
Total & 300 & $100.0 \%$ \\
\hline
\end{tabular}


Table 20. Percentage distribution of the respondents according to their view about children should be married in watta satta marriage arrangements.

\begin{tabular}{ccc}
\hline Children should be married in watta satta marriage arrangement & Frequency & Percent \\
\hline Agree & 19 & $6.33 \%$ \\
Strongly agree & 240 & $80.0 \%$ \\
Neutral & 21 & $7.0 \%$ \\
Disagree & 11 & $3.66 \%$ \\
Strongly disagree & 9 & $3.0 \%$ \\
Total & 300 & $100.0 \%$ \\
\hline
\end{tabular}

Table 21. Association between qualification of the respondents and children should be married in watta satta marriage arrangement.

\begin{tabular}{|c|c|c|c|c|c|c|}
\hline \multirow{2}{*}{$\begin{array}{l}\text { Qualification of } \\
\text { respondents }\end{array}$} & \multicolumn{5}{|c|}{ Do you think that children should be married in watta satta marriage arrangements? } & \multirow[b]{2}{*}{ Total } \\
\hline & Agreed & Strongly Agree & Neutral & Disagree & $\begin{array}{l}\text { Strongly } \\
\text { Disagree }\end{array}$ & \\
\hline Illiterate & 19 & 144 & & & & 163 \\
\hline Literate-Primary & & 72 & & & & 72 \\
\hline Middle-Matric & & 24 & 10 & & & 34 \\
\hline Inter-Graduation & & & 11 & 9 & & 20 \\
\hline Master or Above & & & & 2 & 9 & 11 \\
\hline Total & 19 & 240 & 21 & 11 & 9 & 300 \\
\hline
\end{tabular}

Chi Square Value $=499.436$. Degree of Freedom $=16$. Level of Significance $=0.05$ Significant. Gamma $=1.000$.

Table 22. Association between monthly income and children should be married in watta satta marriage arrangement.

\begin{tabular}{|c|c|c|c|c|c|c|}
\hline \multirow{2}{*}{$\begin{array}{l}\text { What is your } \\
\text { monthly } \\
\text { income? }\end{array}$} & \multicolumn{5}{|c|}{ Do you think that children should be married in watta satta marriage arrangements? } & \multirow[b]{2}{*}{ Total } \\
\hline & Agreed & Strongly Agree & Neutral & Disagree & $\begin{array}{l}\text { Strongly } \\
\text { Disagree }\end{array}$ & \\
\hline $1000-10,000$ & 19 & 188 & & & & 207 \\
\hline $10,000-20,000$ & & 52 & 11 & & & 63 \\
\hline Above 20,000 & & & 10 & 11 & 9 & 30 \\
\hline Total & 19 & 240 & 21 & 11 & 9 & 300 \\
\hline
\end{tabular}

Chi Square Value $=269.674$. Degree of Freedom $=8$. Level of Significance $=5 \%$ Significant. Gamma $=1.000$.

first cousins as well. Exchange marriage conflicts are the major example of stressors. Conflict between one of the couple keeps the whole family and their counterpart family under acute stress and has dangerous effect on psychology of parents and children. Most of failures understanding one another have less to do with what is said and what is heard than with what is intended and what is inferred. Watta satta (Exchange marriage) is prevailing everywhere in Pakistan. This custom is a stone-age custom but practiced in all rural areas of Southern Punjab. However, it is not liked by many of peoples yet it is practiced due to various factors. One of the major factors is poverty after that illiteracy. Some customs and practices are borrowed either from new settlers or followed from their forefathers and neighbors for making life easy and comfortable. Human natures like comfort and ease but on the other hand human being wants to stick with his past. Some customs are good for specific time period. New era have different demands for development if old customs become hurdle for the development of county and prosperity of subject then there is a great need to change these customs and tradition. Increasing the opportunities of education for children may provoke awareness about the negative effects of exchange marriages. The media should play a vital role in highlighting this issue and enlightening the public at large. It should present 
programs and talk shows which sensitize the people about consequences of exchange marriages and about ways and means to counter it. Poverty and illiteracy, which is the mother of all fossilized discriminatory customs, should be abolished. Only through positive and strong role of social change agents can socio-cultural norms of the people towards exchange marriages be positively modified. National and regional working groups should be established to formulate and promote action strategies to reduce exchange marriages and their negative effects. Education should be made essential for all including women.

\section{References}

[1] Zhang, W. (2000) Dynamics of Marriage Change in Chinese Rural Society in Transition, a Study of a Northern Chinese Village. Population Studies, 54, 57-69. http://dx.doi.org/10.1080/713779064

[2] Rose, H. (1908) Hindu Betrothal Observances in the Punjab. The Journal of the Royal Anthropological Institute of Great Britain and Ireland, 38, 409-418. http://dx.doi.org/10.2307/2843307

[3] Bohannan, L. (1949) Dahomean Marriage: A Revaluation, Africa. Journal of the International African Institute, 19, 273-287. http://dx.doi.org/10.2307/1156403

[4] Jacoby, G.H. and Mansuri, G. (2006) Watta satta: Exchange Marriage and Women’s Welfare in Rural Pakistan. The World Bank.

[5] Saeed, R.R. (2005) Socio-Economic, Political \& Gender Situation of Tribal Areas, Women in Sulaiman Mountain Range, Pakistan.

[6] Niaz, U. (2004) Women's mental health in Pakistan. Official journal of World Psychiatric Association, 3, 60-62.

[7] Carsten, J. (1997) The Heat of the Hearth: The Process of Kinship in a Malay Fishing Community. Clarendon, Oxford.

[8] Ahmed (2003) Judgment against Forced Marriage. Daily Times, Lahore, 6 July 2003.

[9] Chaudhry, S. (2004) The Investigation into the Attitude of Rural Women towards Exchange Marriages. Department of Rural Sociology, University of Agriculture Faisalabad, Faisalabad.

[10] Jacoby, G.H. and Mansuri, G. (2004) Pakistan Rural Household Survey (PRHS II). World Bank's Development Research Group (DECRG).

[11] Coomaraswamy, R. (2005) The Varied Contours of Violence against Women in South Asia. 5th South Asia Regional Ministerial Conference, Celebrating Beijing plus Ten Islamabad, Pakistan. Jointly Organised by Government of Pakistan and UNIFEM South Asia Regional Office.

[12] World Bank (2005) Improving Gender Outcomes. The Promise for Pakistan, Environment and Social Development Sector Unit, South Asia Region, Washington DC.

[13] Chaudhry, R. (2006) Survey Conducted in 14 Districts of South Punjab: 2017 Cases of Violence against Women. Awaz Foundation, Multan.

[14] World Bank (2006) Improving Gender Outcomes. The Promise for Pakistan, Environment and Social Development Sector Unit, South Asia Region, Washington DC.

[15] Charsley, K. (2007) Risk, Trust, Gender and Transnational Cousin Marriage among British Pakistanis. Ethnic and Racial Studies, 30, 1117-1131. http://dx.doi.org/10.1080/01419870701599549

[16] Cheema, H. (2008) Gender Discussion: Economic Equity, Asia-Pacific Human Development Report. United Nations Development Programme (UNDP), New York.

[17] Najam, N. (2010) Honour Killings in Pakistan property in Pakistan. International Development Research Centre (IDRC), New Delhi.

[18] Dawn (2011) The Bride Bartered in Marriage Exchange in Rural Pakistan on 7 September 2011. 